\title{
Solving the puzzle of autoimmunity: critical questions
}

\author{
Dawn E. Smilek ${ }^{1}$ and E. William St. Clair ${ }^{1,2 *}$
}

Addresses: ${ }^{1}$ Immune Tolerance Network, 185 Berry Street \#3515, San Francisco, CA 94107, USA; ${ }^{2}$ Department of Medicine, Division of Rheumatology and Immunology, School of Medicine, Duke University, Durham, NC 27710, USA

*Corresponding author: E. William St. Clair (stcla003@mc.duke.edu)

Fl000Prime Reports 2015, 7:17 (doi:10.12703/P7-17)

All Fl000Prime Reports articles are distributed under the terms of the Creative Commons Attribution-Non Commercial License (http://creativecommons.org/licenses/by-nc/3.0/legalcode), which permits non-commercial use, distribution, and reproduction in any medium, provided the original work is properly cited.

The electronic version of this article is the complete one and can be found at: http://fl 000.com/prime/reports/b/7/I7

\begin{abstract}
Despite recent advances in delineating the pathogenic mechanisms of autoimmune disease, the puzzle that reveals the true picture of these diverse immunological disorders is yet to be solved. We know that the human leukocyte antigen (HLA) loci as well as many different genetic susceptibility loci with relatively small effect sizes predispose to various autoimmune diseases and that environmental factors are involved in triggering disease. Models for mechanisms of disease become increasingly complex as relationships between components of both the adaptive and innate immune systems are untangled at the molecular level. In this article, we pose some of the important questions about autoimmunity where the answers will advance our understanding of disease pathogenesis and improve the rational design of novel therapies. How is autoimmunity triggered, and what components of the immune response drive the clinical manifestations of disease? What determines whether a genetically predisposed individual will develop an autoimmune disease? Is restoring immune tolerance the secret to finding cures for autoimmune disease? Current research efforts seek answers to these big questions.
\end{abstract}

\section{Introduction}

Over the past several decades, much has been learned about the pathogenesis of autoimmune diseases, a diverse group of heterogeneous disorders that may be characterized by multi-organ or single-organ system involvement. Underlying these diverse clinical phenotypes is a dysregulated immune system with an enhanced capacity to respond against self. The immune system is normally designed to defend against foreign pathogens by using an array of $\mathrm{T}$ and $\mathrm{B}$ lymphocytes, which bear antigen receptors, and innate immune cells, which may be activated by pathogen- or damage-associated molecular patterns. These cells orchestrate a finely tuned immune response through tightly regulated cell-cell interactions and secretion of cytokines, chemokines, and other inflammatory mediators. The body's defense against foreign pathogens must occur without causing undue harm to self. To accomplish this feat, the bulk of self-reactive $\mathrm{T}$ and $\mathrm{B}$ lymphocytes are eliminated in the thymus and bone marrow through a process of negative selection. However, this process is imperfect, albeit purposely, and self-reactive lymphocytes that escape into the periphery must be kept under wraps by an array of peripheral tolerance mechanisms. When the balance of the effector and regulatory arms of an immune response is thrown off, self-reactive $\mathrm{T}$ and $\mathrm{B}$ cells become activated and promote autoimmunity [1]. What finally pushes the immune system out of balance is a black box.

When speaking of autoimmune diseases, we often consider those featuring immunity against self-antigens and those without detectable anti-self-responses in the same breath. Rheumatoid arthritis (RA), systemic lupus erythematosus (SLE), multiple sclerosis, type 1 diabetes (T1D), and celiac disease are examples of autoimmune diseases associated with the production of autoantibodies and, in some cases, self-reactive T cells. On the other hand, immunity against self-antigens is not a feature of psoriasis, inflammatory bowel disease, or ankylosing spondylitis, although the adaptive immune system is clearly involved in their pathogenesis $[2,3]$. There are some similarities in disease mechanisms because they both respond favorably 
Table I. Critical questions about autoimmunity

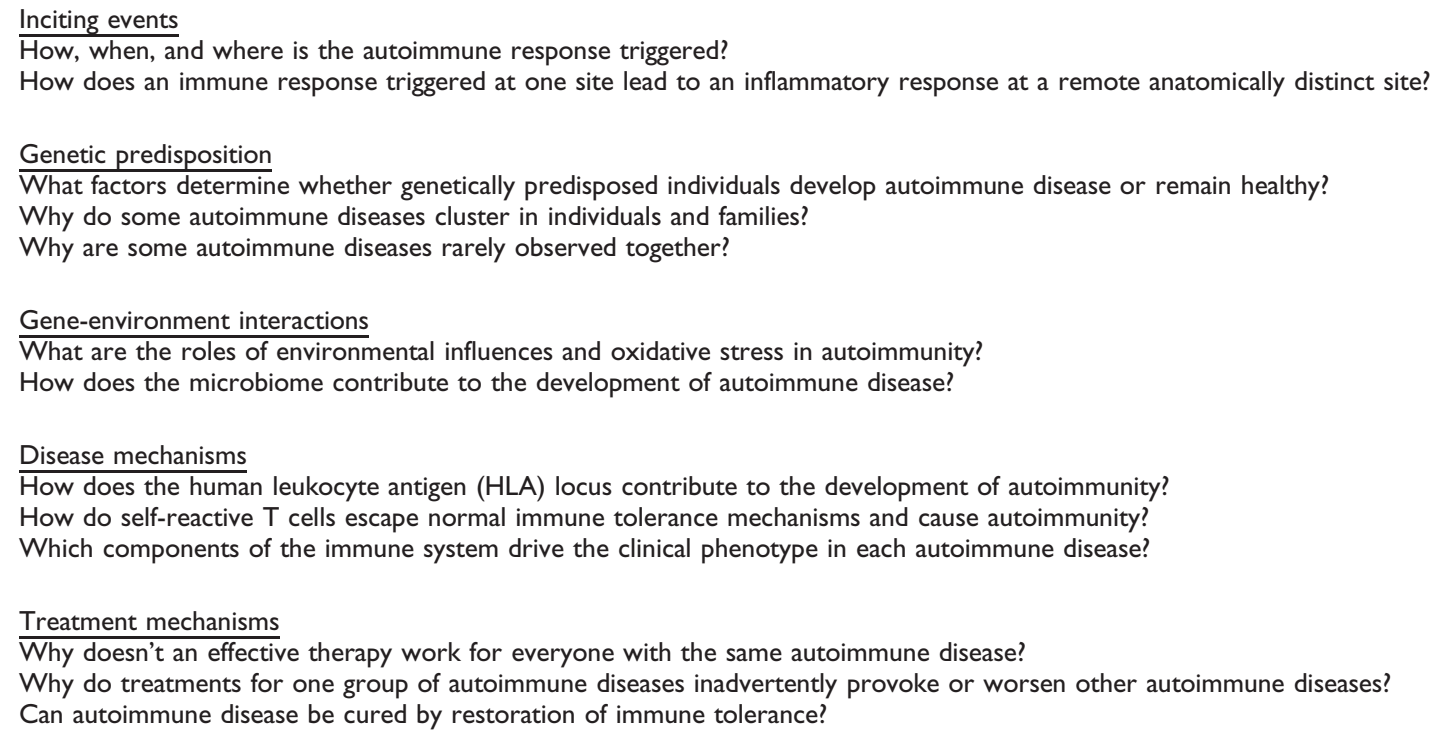

to anti-tumor necrosis factor (anti-TNF) therapy. In contrast, the predominant genetic associations of seropositive and seronegative disease diverge in an important way, namely their relationships with class II and class I HLA risk alleles, respectively.

Despite a growing understanding about the pathogenesis of autoimmune disease, untangling the complex events that provoke autoimmunity, produce clinical disease, and perpetuate its chronicity has been a major challenge. The interrelationships between the causative factors of autoimmune disease-genetics and environment-are mostly a mystery. In most instances, elucidation of the relative contribution of T cells, B cells, myeloid cells, and dendritic cells, as well as other rare cell types, to disease pathogenesis is a work in progress. The mechanisms of tissue inflammation are complex and involve the interactions between multiple immune cell types and an array of mediators that are balanced to favor an effector response.

Arguably, much progress toward understanding disease mechanisms has been made through the discovery of effective therapies that target specific cytokines [4]. These results have revealed vulnerable nodes in the mechanisms of disease, such as TNF in RA, psoriasis, and inflammatory bowel disease. However, a substantial proportion of patients with RA and these other diseases are not responsive to TNF inhibitors, highlighting the heterogeneity of disease and the likely presence of disease subtypes. It has also proven difficult to modulate the immune system for sustained benefit. Therapy such as TNF inhibition that weakens host defense and increases malignancy risk must be maintained indefinitely. The gaps in knowledge about the pathogenesis and treatment of autoimmune disease are evident in this very complicated puzzle. In this article, we discuss some of the critical questions dogging the community of researchers invested in better understanding autoimmunity (Table 1). Others may ask different questions, but it all depends on who is touching what part of the elephant [5]. The geneticist searches for allelic variation in the genes regulating immune pathways that are the driving force behind disease. The epidemiologist focuses on the inciting events. Clinicians who must deal with sick patients regardless of their genetic risks and disease triggers seek biomarkers that can identify disease subtypes and predict treatment response.

\section{The critical questions: pathogenesis of rheumatoid arthritis}

Hypotheses related to the triggering of autoimmune disease are generally framed as a function of the interplay between heredity and the environment. Two critical questions emerge from this organizing principle: (1) Which components of the immune system drive the clinical phenotype in each autoimmune disease? (2) How, when, and where is the autoimmune response triggered? Questions about the disease-inducing immunity have focused on the adaptive immune response (for example, autoantibodies and self-reactive $\mathrm{B}$ and $\mathrm{T}$ cells). How, when, and where disease-inducing immunity is triggered pose further questions about the events leading to the breakdown in immune tolerance and disease perpetuation.

With reference to these questions, it is useful to describe a conceptual model of the pathogenesis of RA, which has 
gained increasing support and implicates triggering immune events at extra-articular sites, such as the lung. This breach in turn promotes immunity against citrullinated proteins in the synovium, the articular cartilage and bone, and consequently the development of chronic joint inflammation [6]. Autoantibodies to post-translationally modified citrullinated proteins (ACPAs) define a clinical phenotype associated with the two major risk factors for RA, the HLA DRB1 shared epitopes and an environmental exposure, cigarette smoking. Together they interact to increase the risk of developing ACPA-positive RA [7]. The R620W allele of PTPN22, a non-HLA genetic risk factor, has a strong effect in models that combine it with these other two major risk factors [8]. Serum ACPAs develop many years before the onset of clinical disease, suggesting that immunity to citrullinated proteins first occurs outside the joints [9]. The initiating events in RA may take place in the lungs. Recent studies indicate that those with or at increased risk for ACPA-positive RA have evidence of local production of ACPA in their bronchoalveolar fluid and lung tissue [10]. The lungs are an attractive candidate for an initiating immune response because of their limited barrier to environmental exposures. Periodontal mucosa also has a limited barrier that could be the site of initiation or amplification of autoimmunity. Bacterial species associated with periodontal disease, such as Porphyromonas gingivalis, have been shown to express the enzyme peptidyl arginine deaminase, which citrullinates human peptides correlated with autoimmunity [11].

How does immunity to citrullinated antigens triggered in the lungs lead to synovial inflammation? Dual expression of the primary targets of ACPAs in the lungs and joints is a possible explanation. Although identical citrullinated proteins are present in bronchial and synovial tissue of patients with RA, it remains unclear how ACPA induces disease in the joints [12]. Indeed, marked hypercitrullination is a feature of the rheumatoid joint [13]. It also appears that the joint is a reservoir of locally produced ACPAs because it has been shown that synovial fluid from ACPA-positive patients contains high titers of these antibodies [14]. In addition, immunoglobulin G-positive B cells that secrete antibodies to citrullinated peptides have been isolated from synovial fluid [15]. Once present in the joint, how does ACPA promote joint inflammation? Antibodies to citrullinated vimentin, another antigen in the joint, have been shown to stimulate osteoclast activation, perhaps contributing to the early stages of joint inflammation (bone marrow edema) and later joint erosions (damage) [16,17]. Immunity to other citrullinated antigens may augment joint inflammation by unknown mechanisms. Citrullinated fibrinogen, for example, may increase the potency of the innate immune response by binding to Toll-like receptor- 4 and Fc $\gamma$ receptor [18]. Another study has shown that citrullination of a chemokine, known as ENA/CXCL5, is higher in serum and synovial fluid from patients with RA than healthy controls and that citrullinated CXCL5 may recruit more monocytes to the inflamed joint than the non-citrullinated chemokine [19].

Although the story remains incomplete, the evolving evidence suggests that a breakdown of immune tolerance in the lungs, potentially induced by cigarette smoking or other exposure, in a genetically predisposed individual with distinct HLA class II alleles and non-HLA alleles, leads to the production of antibodies to citrullinated proteins before disease onset. This hypothesis raises critical questions about the regulation of adaptive immunity in the lungs, its dynamic behavior in relation to external stimuli, and the role of the microbiome in shaping a local immune response. These events in the lungs are followed by unknown events in the joint (perhaps a "second hit") that trigger inflammation. What is the time course of these events? The immune response to citrullinated protein is initially restricted many years before disease onset and later expands with time to target multiple epitopes on different citrullinated proteins near the onset of clinical disease [20]. This feature of epitope spreading leading up to disease onset may be a general feature of autoimmune disease, as illustrated by the evolution of serum autoantibody specificity predating the onset of SLE [21]. In RA and SLE, increased serum levels of chemokines and cytokines also precede the development of symptoms [22,23]. Is epitope spreading a consequence of an evolving systemic inflammatory response prior to onset of clinical disease, or a factor contributing to the development of tissue inflammation, or both?

\section{Environmental control of autoimmunity: epigenetics and the microbiome}

What factors determine whether genetically susceptible individuals will develop an autoimmune disease? Twin studies show that the environment influences the development of autoimmunity [24], and many environmental agents have been linked to autoimmune diseases [25]. Some environmental factors may contribute to autoimmunity by epigenetic mechanisms. Epigenetic mechanisms are heritable changes in gene expression that are not encoded in the DNA sequence but that are replicated each time a cell divides. DNA methylation and histone modifications are epigenetic mechanisms that control gene expression at the transcriptional level and thus are central to lymphocyte subset development and effector function. Epigenetic mechanisms are susceptible to environmental influences such as drugs, toxins, oxidative stress, and hormones, which trigger or exacerbate autoimmune diseases such as SLE in genetically predisposed individuals $[26,27]$. 
DNA methylation typically represses gene expression, and factors that inhibit methylation can promote expression of genes which are normally silenced. Decreased DNA methylation secondary to environmental exposures and oxidative stress converts $\mathrm{T}$ cells into a pro-inflammatory self-reactive phenotype that causes a lupus-like syndrome in mice [28]. Patients with active SLE have T cells with similar epigenetic changes and overexpression of genes that are normally silenced by DNA methylation [29]. There is evidence that drugs such as procainamide and hydralazine cause SLE by this mechanism in genetically susceptible individuals [28]. Decreased DNA methylation due to oxidative stress and other environmental factors may also be relevant in SLE occurring in the absence of known triggers [27].

The concept of environment has expanded from exogenous triggers, such as infection and toxic exposures, to endogenous triggers harbored in the microbiome. The complex relationships between commensal bacteria and autoimmunity are not well understood, but increasing evidence suggests that the microbiome may play an important role in the development of autoimmune disease [30,31]. One unusual species, segmented filamentous bacteria, induces an intestinal pro-inflammatory subset of $\mathrm{T}$ lymphocytes known as $\mathrm{T}$ helper 17 (Th17) cells [32], which have been implicated in a number of autoimmune diseases [33]. This species of bacteria also promotes autoimmune arthritis and experimental autoimmune encephalomyelitis at sites remote from the intestine in animal models $[34,35]$. A recent study in humans examined fecal microbiota in new-onset RA by sequencing microbial $16 \mathrm{~S}$ ribosomal RNA genes [36]. An impressive $75 \%$ of patients with new-onset untreated RA had evidence of Prevotella copri colonization, compared with only $21 \%$ of healthy control subjects and $12 \%$ of subjects with treated chronic RA. These data raise new questions about the relationship between gut colonization and pathogenesis of RA as well as additional questions about how commensal bacteria influence autoimmunity in general.

\section{Genetic susceptibility: human leukocyte antigen and the role of adaptive immunity}

The first known autoimmune disease-associated gene complex was the HLA locus, which even today predominates over other genetic associations. Proteins encoded by HLA alleles are central to the adaptive immune response by binding antigenic peptide fragments which, in turn, recognize $\mathrm{T}$ lymphocytes. How does this normal function of HLA molecules contribute to autoimmune disease? The working hypothesis for this striking HLA disease association has been that allele-specific HLA molecules bind self-peptides, or peptides that mimic self, in a unique conformation that is recognized by self-reactive $\mathrm{T}$ cells. Such self-reactive $\mathrm{T}$ cells might ordinarily be eliminated by negative selection in the thymus or controlled by peripheral tolerance mechanisms, such as induction of anergy or suppression by $\mathrm{T}$ regulatory cells $[1,37]$. Why do self-reactive $T$ cells escape normal immune tolerance mechanisms and cause autoimmune disease? This question remains unanswered today and likely involves disruption of the fine balance between effector and regulatory immune compartments.

Some self-peptides bind to HLA molecules weakly; preproinsulin peptides in $\mathrm{T} 1 \mathrm{D}$, for example, bind with low affinity to HLA-A2 [38]. Despite weak binding of the peptides to HLA, T cells in the peripheral blood of T1D subjects recognize these low-affinity peptide-HLA complexes, suggesting that low-affinity peptide-HLA interactions might trigger low-affinity $\mathrm{T}$ cells that are less subject to control by normal tolerance mechanisms such as negative selection and anergy. A recent study has shown that T-cell responses to a low-affinity insulin peptide are present in T1D subjects but not normal controls. Interestingly, these $\mathrm{T}$ cells also recognize microbial antigens, suggesting a mechanism by which infection could lead to disease [39]. Such low-affinity T cells could escape tolerance mechanisms, persist in the body, and when unchecked cause autoimmune disease.

Some self-antigens are created in response to environmental triggers in genetically susceptible individuals. A previously cited example is the citrullination of proteins that occurs in genetically susceptible smokers prior to the development of RA. Environmental factors can also trigger disease by inducing unexpected alterations of the peptide-HLA complex recognized by T cells, as recently demonstrated for beryllium-associated inflammatory lung disease. Chronic beryllium disease has been described as a $\mathrm{T}$ cell-mediated allergic hypersensitivity illness but shares a number of features with autoimmune diseases, including a close association with HLA. The immune response in chronic beryllium disease involves T-cell reactivity to self-peptide-HLA complexes in which the beryllium cation is bound deeply buried within the complex rather than at the surface of the complex. The beryllium cation thus does not contact the T-cell receptor itself but rather alters the surface conformation of selfpeptide HLA complexes such that they are recognized as novel by T cells [40].

HLA class I and II molecules are the strongest genetic risk factors for many autoimmune diseases. In several cases, such as RA, disease-promoting class II HLA polymorphisms are located in the antigen-binding groove, implying that altered presentation of self-peptides underlies 
disease pathogenesis [41]. HLA class I molecules present endogenous peptides from self-proteins and intracellular pathogens for binding by cytotoxic T cells (CTLs). The association between HLA-B27 and the spondyloarthropathies, including reactive arthritis, is the strongest genetic risk between an HLA class I allele and a human autoimmune disease; however, the mechanisms behind this genetic association remain to be defined. HLA-B27restricted epitopes from Chalmydia trachomatis are recognized by specific CTLs from patients with reactive arthritis; these epitopes show high sequence homology with HLA-B27 self-peptides, suggesting that molecular mimicry is a possible mechanism by which class I HLA molecules may be linked with the pathogenesis of disease [42]. Another possibility relates to the observation that cytokine-induced HLA-B27 upregulation in macrophages results in a robust induction of the unfolded protein response (UPR) [43]. Although UPR activation has been associated with amplification of immune and inflammatory responses, direct evidence that these events act upstream of cell signaling and contribute to human disease pathogenesis is lacking [44].

\section{Genetic elements and immune pathways that contribute to autoimmune disease}

Which autoimmune disease will a genetically susceptible individual develop? In addition to HLA, a large number of autoimmune-predisposing genes have been identified $[45,46]$. Some genetic variants lead to severe autoimmune syndromes and are observed rarely in the population [47]. One such example is the genetic variant encoding the autoimmune regulator AIRE, a transcription factor required for the ectopic expression of tissue-specific antigens in the thymus. Loss-of-function variants of AIRE defect disrupt negative selection of self-reactive $\mathrm{T}$ lymphocytes, leading to autoimmunity at various sites $[48,49]$.

The vast majority of the genetic loci associated with increased susceptibility to autoimmune disease are also found in healthy individuals. Most of these susceptibility genes have been identified by genome-wide association studies and Immunochip studies, and many are known to affect critical immune pathways $[45,46]$. There are also unaccounted-for genetic contributions known as "missing heritability". Some of this missing heritability may be due to relatively common loci with small effect sizes [50]. Alternatively, rare variants with large effect sizes may escape detection in genome-wide association studies [51]. Since risk alleles are found mostly in both healthy and autoimmune individuals, it is likely that the combination of many different loci interacting with environment factors promotes autoimmune disease.
Autoimmunity appears to be inherited as a trait. Individuals with one autoimmune disease are at higher risk of developing a second autoimmune disease, and multiple autoimmune diseases cluster within families [52]. Autoantibody-mediated (seropositive) diseases, such as RA, $\mathrm{T} 1 \mathrm{D}$, and autoimmune thyroid disease, occur in clusters. This clustering is likely explained by susceptibility gene variants in common among the diseases. One prominent example is the single-nucleotide polymorphism variant PTPN22, which is a risk allele for RA, T1D, SLE, and other autoimmune diseases [53-56]. PTPN22 encodes lymphocyte tyrosine phosphatase, a negative regulator of T-cell activation. Altered T-cell receptor (TCR) signaling has been reported in the setting of the autoimmunity-associated PTPN22 variant $[57,58]$. Lymphocyte tyrosine phosphatase is expressed not only in T cells but also in B cells and myeloid cells. The variant allele of PTPN22 has been associated with defective B-cell tolerance and abnormally high numbers of self-reactive B cells [59-61]. The PTPN22 variant of lymphocyte tyrosine phosphatase also regulates type I interferon production following Toll-like receptordriven activation of myeloid cells, an observation that suggests a possible link between infections and autoimmune disease [62]. PTPN22-related defects in the T cell, B cell, and innate immune compartments could in theory contribute to disease in many different organ systems and, depending on the presence of other gene loci, produce a variety of clinical phenotypes [56].

Autoimmune diseases without autoantibodies (seronegative), such as psoriasis, inflammatory bowel disease, and ankylosing spondylitis, also show evidence of clustering. These seemingly unrelated diseases share an association with spondyloarthropathy, which is characterized by sacroiliitis and enthesitis (inflammation of tendons and ligaments at insertion sites) rather than the synovial inflammation typical of RA. Psoriasis and inflammatory bowel disease are associated with gene variants of the interleukin-23 (IL-23) receptor [63,64]. IL-23 is a cytokine that supports the development of Th17 cells, which produce the pro-inflammatory cytokine IL-17 as well as other IL-17-producing cell types [65]. Notably, there is much higher correlation between susceptibility genes for ankylosing spondylitis and psoriasis than between genes for ankylosing spondylitis and RA [45].

Unifying diseases into a single diagnostic category may not be particularly useful, since the molecular pathways contributing to disease pathogenesis are likely related in some cases but highly distinct in others. This concept has major implications for drug development and repurposing of approved medications for new indications [66]. Discordant sets of genetic susceptibility genes may 
also explain why therapy for one autoimmune disease can inadvertently trigger another autoimmune disease. One example is a variant of the TNF receptor that is associated with an increased risk for multiple sclerosis but which is protective against developing ankylosing spondylitis [67]. Perhaps not surprisingly then, anti-TNF therapy, though effective for ankylosing spondylitis, has been shown to worsen multiple sclerosis and may induce a multiple sclerosis-like disease as an adverse consequence of treatment [68].

\section{Disease heterogeneity: variable response to therapeutic intervention}

When a therapy is effective in an autoimmune disease, why does it not work for everyone with that disease? Within a given autoimmune disease, there is heterogeneity in clinical phenotypes, implying differences among individuals in pathogenic mechanisms. Thus, it is not surprising that individuals within a diagnostic category vary in their response to therapy. In relapsingremitting multiple sclerosis, for which type I interferon (interferon beta) is considered standard first-line therapy, $30 \%$ to $50 \%$ of patients do not respond to this intervention. Somewhat paradoxically, in multiple sclerosis, elevated expression of type I interferon response genes pre-treatment correlates with the absence of a beneficial response to type I interferontherapy $[69,70]$. It has been suggested that a high-interferon response gene signature identifies a subset of patients with multiple sclerosis who have a distinctly different pathogenic mechanism driving disease [71]. Similarly, in RA, an interferon response gene signature has been found to predict a lack of response to rituximab therapy [72-74]. "Personalizing" treatment of autoimmune disease on the basis of genetic factors, biomarkers, and lifestyle choices has the potential to dramatically improve the therapeutic approach for many autoimmune diseases [75].

\section{Restoration of immune tolerance as a treatment for autoimmunity}

Amelioration of clinical disease is not usually durable without ongoing therapy and often requires frequent switching of drugs to sustain disease control. To keep disease at bay, combined interventions may be needed to simultaneously check effector lymphocytes, potentiate regulatory elements, and control the innate immune response [76]. Even if such combinations are successful in remediating the manifestations of autoimmune disease, it remains to be proven whether durable immune tolerance and a healthy state can be restored in the autoimmune disease setting without changing genetic predisposition or reversing the environmental damage. Prevention may yet prove to be the optimal treatment strategy.

\section{Conclusions}

A complex picture of autoimmune pathogenesis is emerging in which genetic predisposition resides in a large number of loci encoding key immune pathway molecules. We now recognize that expression of these genes is under epigenetic control, which can be influenced by a number of environmental factors in susceptible individuals. The microbiome resides at the boundary of self and the environment and appears to also influence autoimmunity by mechanisms that are not yet understood. Although progress has been made in understanding the pathogenesis of autoimmune disease, a large number of questions remain unanswered (Table 1). Filling this gap in knowledge will require a greater understanding of the inciting events leading to autoimmunity and clinical disease, the role of the environment (including the microbiome) in triggering and perpetuating disease, the hierarchy of aberrantly regulated immune pathways involved in disease pathogenesis, and identification of the most vulnerable nodes in the immune system for therapeutic targeting. We expect too that the nosology for autoimmune disease will slowly evolve from its current framework of clinical and serologically defined states into an immune pathway-based scheme of overlapping phenotypes and sub-phenotypes that will underpin rationally designed therapy in the future. The pieces of the puzzle are slowly coming together.

\section{Abbreviations}

ACPA, autoantibody to citrullinated proteins; CTL, cytotoxic T cell; HLA, human leukocyte antigen; IL, interleukin; RA, rheumatoid arthritis; SLE, systemic lupus erythematosus; T1D, type 1 diabetes; Th17, T helper 17; TNF, tumor necrosis factor; UPR, unfolded protein response.

\section{Disclosures}

E. William St. Clair has received in-kind support from Biogen Idec for a National Institute of Allergy and Infectious Diseases (NIAID)-sponsored trial of a novel therapy for Sjögren's syndrome. He also serves as a deputy director for the Immune Tolerance Network, an NIAID-funded consortium dedicated to the development of tolerance-inducing therapies for allergy and asthma, autoimmune disease, and transplant. Dawn E. Smilek is associate director of clinical development for the Immune Tolerance Network.

\section{Acknowledgments}

The authors thank their colleagues at the Immune Tolerance Network and their collaborators who contribute in many capacities to Immune Tolerance Network projects and perspectives. 


\section{References}

I. Bluestone JA: Mechanisms of tolerance. Immunol Rev 20 I I, 24 I :5- I9.

2. Sherlock JP, Buckley CD, Cua DJ: The critical role of interleukin23 in spondyloarthropathy. Mol Immunol 2014, 57:38-43.

3. Lowes MA, Suarez-Farinas M, Krueger JG: Immunology of psoriasis. Annu Rev Immunol 2014, 32:227-55.

4. St Clair EW: Novel targeted therapies for autoimmunity. Curr Opin Immunol 2009, 21:648-57.

5. Saxe J: The blind men and the elephant. in The Poems. Washington: Library of Congress, 1873:260. https://archive.org/stream/poemsjohngodfre02saxegoog\#page/n276/mode/2up.

6. Catrina Al, Ytterberg AJ, Reynisdottir G, Malmström V, Klareskog L: Lungs, joints and immunity against citrullinated proteins in rheumatoid arthritis. Nat Rev Rheumatol 2014, 10:645-53.

7. Klareskog L, Stolt P, Lundberg K, Källberg H, Bengtsson C, Grunewald J, Rönnelid J, Harris HE, Ulfgren AK, Rantapää-Dahlqvist S, Eklund A, Padyukov L, Alfredsson L: A new model for an etiology of rheumatoid arthritis: smoking may trigger HLA-DR (shared epitope)-restricted immune reactions to autoantigens modified by citrullination. Arthritis Rheum 2006, 54:38-46.

\section{FIOOOPrime
RECOMMENDED}

8. Klareskog L, Malmström V, Lundberg K, Padyukov L, Alfredsson L: Smoking, citrullination and genetic variability in the immunopathogenesis of rheumatoid arthritis. Semin Immunol 201 I , 23:92-8.

9. Nielen M, van Schaardenburg D, Reesink HW, van de Stadt RJ, van der Horst-Bruinsma IE, de Koning MH, Habibuw MR, Vandenbroucke JP, Dijkmans BA: Specific autoantibodies precede the symptoms of rheumatoid arthritis: a study of serial measurements in blood donors. Arthritis Rheum 2004, 50:380-6.

10. Perry E, Kelly C, Eggleton P, De Soyza A, Hutchinson D: The lung in ACPA-positive rheumatoid arthritis: an initiating site of injury? Rheumatology (Oxford) 2014, 53:1940-50.

II. Scher JU, Bretz WA, Abramson SB: Periodontal disease and sublingual microbiota as contributors for rheumatoid arthritis pathogenesis: modifiable risk factors? Curr Opin Rheumatol 20|4, 26:424-9.

12. Ytterberg AJ, Joshua V, Reynisdottir G, Tarasova NK, Rutishauser D, Ossipova E, Haj Hensvold A, Eklund A, Sköld CM, Grunewald J, Malmström V, Jakobsson PJ, Rönnelid J, Padyukov L, Zubarev RA, Klareskog L, Catrina Al: Shared immunological targets in the lungs and joints of patients with rheumatoid arthritis: identification and validation. Ann Rheum Dis 2014.

\section{FlOOOPrime}

\section{RECOMMENDED}

13. Romero V, Fert-Bober J, Nigrovic PA, Darrah E, Haque UJ, Lee DM, van Eyk J, Rosen A, Andrade F: Immune-mediated pore-forming pathways induce cellular hypercitrullination and generate citrullinated autoantigens in rheumatoid arthritis. Sci Transl Med 2013, 5:209ral50.

\section{FlOOOPrime}

\section{RECOMMENDED}

14. Snir O, Widhe M, Hermansson M, von Spee C, Lindberg J, Hensen S, Lundberg K, Engström A, Venables PJ, Toes RE, Holmdahl R, Klareskog L, Malmström V: Antibodies to several citrullinated antigens are enriched in the joints of rheumatoid arthritis patients. Arthritis Rheum 2010, 62:44-52.

15. Amara K, Steen J, Murray F, Morbach H, Fernandez-Rodriguez BM, Joshua V, Engström M, Snir O, Israelsson L, Catrina AI, Wardemann H, Corti D, Meffre E, Klareskog L, Malmström V: Monoclonal IgG antibodies generated from joint-derived $B$ cells of RA patients have a strong bias toward citrullinated autoantigen recognition. J Exp Med 2013, 21 0:445-55.

\section{FlOOOPrime}

\section{RECOMMENDED}

16. Harre U, Georgess D, Bang H, Bozec A, Axmann R, Ossipova E, Jakobsson PJ, Baum W, Nimmerjahn F, Szarka E, Sarmay G,
Krumbholz G, Neumann E, Toes R, Scherer HU, Catrina Al, Klareskog L, Jurdic P, Schett G: Induction of osteoclastogenesis and bone loss by human autoantibodies against citrullinated vimentin. J Clin Invest 2012, I 22: |79|-802.

\section{FIOOOPRIMP
RECOMMENDED}

17. Kleyer A, Finzel S, Rech J, Manger B, Krieter M, Faustini F, Araujo E, Hueber AJ, Harre U, Engelke K, Schett G: Bone loss before the clinical onset of rheumatoid arthritis in subjects with anticitrullinated protein antibodies. Ann Rheum Dis 2014, 73:854-60.

\section{FlOOOPrime}

RECOMMENDED

18. Sokolove J, Zhao $X$, Chandra PE, Robinson $\mathrm{WH}$ : Immune complexes containing citrullinated fibrinogen costimulate macrophages via Toll-like receptor 4 and Fcgamma receptor. Arthritis Rheum 2011, 63:53-62.

\section{FlOOOPrime
RECOMMENDED}

19. Yoshida K, Korchynskyi O, Tak PP, Isozaki T, Ruth JH, Campbell PL, Baeten DL, Gerlag DM, Amin MA, Koch AE: Citrullination of ENA78/CXCL5 results in conversion from a non-monocyte recruiting to a monocyte recruiting chemokine. Arthritis Rheumatol 2014, 66:2716-27.

\section{FlOOOPrime}

\section{RECOMMENDED}

20. Brink M, Hansson M, Mathsson L, Jakobsson PJ, Holmdahl R, Hallmans G, Stenlund H, Rönnelid J, Klareskog L, RantapääDahlqvist S: Multiplex analyses of antibodies against citrullinated peptides in individuals prior to development of rheumatoid arthritis. Arthritis Rheum 2013, 65:899-910.

\section{FlOOOPrime}

21. Eriksson C, Kokkonen H, Johansson M, Hallmans G, Wadell G, Rantapää-Dahlqvist S: Autoantibodies predate the onset of systemic lupus erythematosus in northern Sweden. Arthritis Res Ther 20I I, I3:R30.

\section{FlOOOPRIMP
RECOMMENDED}

22. Deane KD, O'Donnell $\mathrm{Cl}$, Hueber $\mathrm{W}$, Majka DS, Lazar AA, Derber LA, Gilliland WR, Edison JD, Norris JM, Robinson WH, Holers VM: The number of elevated cytokines and chemokines in preclinical seropositive rheumatoid arthritis predicts time to diagnosis in an age-dependent manner. Arthritis Rheum 2010, 62:3161-72.

\section{FlOOOPrime}

\section{RECOMMENDED}

23. Eriksson C, Rantapaa-Dahlqvist S: Cytokines in relation to autoantibodies before onset of symptoms for systemic lupus erythematosus. Lupus 2014, [Epub ahead of print].

\section{FlOOOPrime
RECOMMENDED}

24. Twin studies in autoimmune disease: genetics, gender and environment: Twin studies in autoimmune disease: genetics, gender and environment. J Autoimmun 2012, 38:J156-69.

25. Parks CG, Miller FW, Pollard KM, Selmi C, Germolec D, Joyce K, Rose NR, Humble M: Expert panel workshop consensus statement on the role of the environment in the development of autoimmune disease. Int J Mol Sci 2014, I5: |4269-97.

26. Richardson BC, Patel DR: Epigenetics in 2013. DNA methylation and miRNA-key roles in systemic autoimmunity. Nat Rev Rheumatol 2014, 10:72-4.

27. Somers EC, Richardson BC: Environmental exposures, epigenetic changes and the risk of lupus. Lupus 20I4, 23:568-76.

28. Richardson B: Primer: epigenetics of autoimmunity. Nat Clin Pract Rheumatol 2007, 3:521-7. 
29. Li Y, Gorelik G, Strickland FM, Richardson BC: Oxidative stress, T cell DNA methylation, and lupus. Arthritis Rheumatol 2014, 66: I574-82.

30. Ivanov II, Honda K: Intestinal commensal microbes as immune modulators. Cell Host Microbe 2012, I 2:496-508.

31. Hooper LV, Littman DR, Macpherson AJ: Interactions between the microbiota and the immune system. Science 20I2, 336:I268-73.

32. Ivanov II, Atarashi K, Manel N, Brodie EL, Shima T, Karaoz U, Wei D, Goldfarb KC, Santee CA, Lynch SV, Tanoue T, Imaoka A, Itoh K, Takeda K, Umesaki Y, Honda K, Littman DR: Induction of intestinal ThI7 cells by segmented filamentous bacteria. Cell 2009, 139:485-98.

\section{FlOOOPrime}

\section{RECOMMENDED}

33. Singh RP, Hasan S, Sharma S, Nagra S, Yamaguchi DT, Wong DT, $\mathrm{Hahn} \mathrm{BH}$, Hossain $\mathrm{A}$ : ThI7 cells in inflammation and autoimmunity. Autoimmun Rev 2014, I3: I I74-8I.

34. Wu HJ, Ivanov II, Darce J, Hattori K, Shima T, Umesaki Y, Littman DR, Benoist C, Mathis D: Gut-residing segmented filamentous bacteria drive autoimmune arthritis via $T$ helper 17 cells. Immunity 2010, 32:8I5-27.

\section{FlOOOPrime}

\section{RECOMMENDED}

35. Lee YK, Menezes JS, Umesaki Y, Mazmanian SK: Proinflammatory $\mathbf{T}$-cell responses to gut microbiota promote experimental autoimmune encephalomyelitis. Proc Natl Acad Sci USA 201I, I 08(Suppl I):46 I5-22.

\section{FlOOOPrime
RECOMMENDED}

36. Scher JU, Sczesnak A, Longman RS, Segata N, Ubeda C, Bielski C, Rostron T, Cerundolo V, Pamer EG, Abramson SB, Huttenhower C, Littman DR: Expansion of intestinal Prevotella copri correlates with enhanced susceptibility to arthritis. Elife 20I3, 2:e0I202.

\section{FlOOPrime}

\section{RECOMMENDED}

37. Goodnow CCI, Sprent J, Fazekas de St Groth B, Vinuesa CG: Cellular and genetic mechanisms of self tolerance and autoimmunity. Nature 2005, 435:590-7.

38. Abreu JR, Martina S, Verrijn Stuart AA, Fillié YE, Franken KL, Drijfhout JW, Roep BO: CD8 $T$ cell autoreactivity to preproinsulin epitopes with very lowhuman leucocyte antigen class I binding affinity. Clin Exp Immunol 20I2, I 70:57-65.

\section{FlOOPrime}

\section{RECOMMENDED}

39. Yang J, Chow IT, Sosinowski T, Torres-Chinn N, Greenbaum C], James EA, Kappler JW, Davidson HW, Kwok W: Autoreactive $T$ cells specific for insulin $B: I \mid-23$ recognize a low-affinity peptide register in human subjects with autoimmune diabetes. Proc Natl Acad Sci USA 20 |4, I I I: |4840- | 4845.

\section{FlOOOPrime}

\section{RECOMMENDED}

40. Clayton GM, Wang Y, Crawford F, Novikov A, Wimberly BT, Kieft JS, Falta MT, Bowerman NA, Marrack P, Fontenot AP, Dai S, Kappler JW: Structural basis of chronic beryllium disease: linking allergic hypersensitivity and autoimmunity. Cell 20|4, I58:|32-42.

\section{FlOOOPrime \\ RECOMMENDED}

4I. Tsai S, Santamaria P: MHC class II polymorphisms, autoreactive T-cells, and autoimmunity. Front Immunol 20I3, 4:I-7.

42. Alvarez-Navarro C, Cragnolini JJ, Dos Santos HG, Barnea E, Admon A, Morreale A, López de Castro JA: Novel HLA-B27restricted epitopes from Chlamydia trachomatis generated upon endogenous processing of bacterial proteins suggest a role of molecular mimicry in reactive arthritis. J Biol Chem 2013, 288:25810-25.
43. Turner MJ, Delay ML, Bai S, Klenk E, Colbert RA: HLA-B27 upregulation causes accumulation of misfolded heavy chains and correlates with the magnitude of the unfolded protein response in transgenic rats. Arthritis Rheum 2007, 56:215-23.

\section{FlOOOPrime
RECOMMENDED}

44. Colbert RA, Tran TM, Layh-Schmitt G: HLA-B27 misfolding and ankylosing spondylitis. Mol Immunol 20I4, 57:44-5I.

\section{FlOOOPrime}

\section{RECOMMENDED}

45. Parkes M, Cortes A, van Heel DA, Brown MA: Genetic insights into common pathways and complex relationships among immune-mediated diseases. Nat Rev Genet 2013, 14:66I-73.

46. Cho JH, Gregersen PK: Genomics and the multifactorial nature of human autoimmune disease. N Engl J Med 20I I, 365:1612-23.

47. Nagamine K, Peterson P, Scott HS, Kudoh J, Minoshima S, Heino M, Krohn KJ, Lalioti MD, Mullis PE, Antonarakis SE, Kawasaki K, Asakawa S, Ito F, Shimizu N: Positional cloning of the APECED gene. Nat Genet 1997, 17:393-8.

48. Anderson MSI, Venanzi ES, Klein L, Chen Z, Berzins SP, Turley SJ, von Boehmer H, Bronson R, Dierich A, Benoist C, Mathis D: Projection of an immunological self shadow within the thymus by the aire protein. Science 2002, 298: |395-40|.

\section{FIOOOPRIM
RECOMMENDED}

49. Anderson MS, Su MA: Aire and T cell development. Curr Opin Immunol 201 I, 23:198-206.

50. Hunt KA, Mistry V, Bockett NA, Ahmad T, Ban M, Barker JN, Barrett JC, Blackburn H, Brand O, Burren O, Capon F, Compston A, Gough SC, Jostins L, Kong Y, Lee JC, Lek M, MacArthur DG, Mansfield JC, Mathew CG, Mein CA, Mirza M, Nutland S, OnengutGumuscu S, Papouli E, Parkes M, Rich SS, Sawcer S, Satsangi J, Simmonds MJ, Trembath RC, Walker NM, Wozniak E, Todd JA, Simpson MA, Plagnol V, van Heel DA: Negligible impact of rare autoimmune-locus coding-region variants on missing heritability. Nature 2013, 498:232-5.

\section{FlOOOPrime
RECOMMENDED}

5I. Surolia I, Pirnie SP, Chellappa V, Taylor KN, Cariappa A, Moya J, Liu H, Bell DW, Driscoll DR, Diederichs S, Haider K, Netravali I, Le S, Elia R, Dow E, Lee A, Freudenberg J, De Jager PL, Chretien Y, Varki A, MacDonald ME, Gillis T, Behrens TW, Bloch D, Collier D, Korzenik J, Podolsky DK, Hafler D, Murali M, Sands B, Stone JH, Gregersen PK, Pillai S: Functionally defedtive germline variants of sialic acid acetylesterase in autoimmunity. Nature 2010, 466:243-7.

\section{FlOOOPrime} RECOMMENDED

52. Cárdenas-Roldán J, Rojas-Villarraga A, Anaya JM: How do autoimmune diseases cluster in families? A systematic review and meta-analysis. BMC Med 2013, I I:73.

53. Begovich AB, Carlton VE, Honigberg LA, Schrodi SJ, Chokkalingam AP, Alexander HC, Ardlie KG, Huang Q, Smith AM, Spoerke JM, Conn MT, Chang M, Chang SY, Saiki RK, Catanese JJ, Leong DU, Garcia VE, McAllister LB, Jeffery DA, Lee AT, Batliwalla F, Remmers E, Criswell LA, Seldin MF, Kastner DL, Amos Cl, Sninsky JJ, Gregersen PK: A missense single-nucleotide polymorphism in a gene encoding a protein tyrosine phosphatase (PTPN22) is associated with rheumatoid arthritis. Am J Hum Genet 2004, 75:330-7.

\section{FIOOOPrime
RECOMMENDED}

54. Kyogoku C, Langefeld CD, Ortmann WA, Lee A, Selby S, Carlton VE, Chang M, Ramos P, Baechler EC, Batliwalla FM, Novitzke J, Williams AH, Gillett C, Rodine P, Graham RR, Ardlie KG, Gaffney PM, Moser KL, Petri M, Begovich AB, Gregersen PK, Behrens TW: Genetic association of the $\mathrm{R} 620 \mathrm{~W}$ polymorphism of protein tyrosine 
phosphatase PTPN22 with human SLE. Am J Hum Genet 2004, 75:504-7.

\section{FIOOOPrime}

55. Criswell LA, Pfeiffer KA, Lum RF, Gonzales B, Novitzke J, Kern M, Moser KL, Begovich AB, Carlton VE, Li W, Lee AT, Ortmann W, Behrens TW, Gregersen PK: Analysis of families in the multiple autoimmune disease genetics consortium (MADGC) collection: the PTPN22 620W allele associates with multiple autoimmune phenotypes. Am J Hum Genet 2005, 76:56I-7I.

\section{FlOOOPrime} RECOMMENDED

56. Stanford SM, Bottini N: PTPN22: the archetypal non-HLA autoimmunity gene. Nat Rev Rheumatol 2014, 10:602-II.

57. Rieck M, Arechiga A, Onengut-Gumuscu S, Greenbaum C, Concannon P, Buckner JH: Genetic variation in PTPN22 corresponds to altered function of $\mathbf{T}$ and B lymphocytes. J Immunol 2007, 179:4704-10.

\section{FlOOOPrime} RECOMMENDED

58. Zhang J, Zahir N, Jiang Q, Miliotis H, Heyraud S, Meng X, Dong B, Xie G, Qiu F, Hao Z, McCulloch CA, Keystone EC, Peterson AC, Siminovitch KA: The autoimmune disease-associated PTPN22 variant promotes calpain-mediated Lyp/Pep degradation associated with lymphocyte and dendritic cell hyperresponsiveness. Nat Genet 20I I, 43:902-7.

\section{FlOOOPrime RECOMMENDED}

59. Menard L, Saadoun D, Isnardi I, Ng YS, Meyers G, Massad C, Price C, Abraham C, Motaghedi R, Buckner JH, Gregersen PK, Meffre E: The PTPN22 allele encoding an R620W variant interferes with the removal of developing autoreactive $B$ cells in humans. I Clin Invest 201 I, I21:3635-44.

\section{F1OOOPrime RECOMMENDED}

60. Habib T, Funk A, Rieck M, Brahmandam A, Dai X, Panigrahi AK, Luning Prak ET, Meyer-Bahlburg A, Sanda S, Greenbaum C, Rawlings DJ, Buckner JH: Altered B cell homeostasis is associated with type I diabetes and carriers of the PTPN22 allelic variant. J Immunol 20I2, I 88:487-96.

61. Nepom GT, Buckner JH: A functional framework for interpretation of genetic associations in TID. Curr Opin Immunol 20I2, 24:516-2I.

62. Wang Y, Shaked I, Stanford SM, Zhou W, Curtsinger JM, Mikulski Z, Shaheen ZR, Cheng G, Sawatzke K, Campbell AM, Auger JL, Bilgic H, Shoyama FM, Schmeling DO, Balfour HH Jr, Hasegawa K, Chan AC, Corbett JA, Binstadt BA, Mescher MF, Ley K, Bottini N, Peterson E): The autoimmunity-associated gene PTPN22 potentiates tolllike receptor-driven, type I interferon-dependent immunity. Immunity 2013, 39: I II-22.

\section{FlOOOPRime
RECOMMENDED}

63. Duerr RH, Taylor KD, Brant SR, Rioux JD, Silverberg MS, Daly MJ, Steinhart AH, Abraham C, Regueiro M, Griffiths A, Dassopoulos T, Bitton A, Yang H, Targan S, Datta LW, Kistner EO, Schumm LP, Lee AT, Gregersen PK, Barmada MM, Rotter Jl, Nicolae DL, Cho JH: A genome-wide association study identifies IL23R as an inflammatory bowel disease gene. Science 2006, 3 | 4:| |46|-3.

\section{FlOOOPrime}

\section{RECOMMENDED}

64. Cargill M, Schrodi SJ, Chang M, Garcia VE, Brandon R, Callis KP, Matsunami N, Ardlie KG, Civello D, Catanese JJ, Leong DU, Panko JM, McAllister LB, Hansen CB, Papenfuss J, Prescott SM, White T], Leppert MF, Krueger GG, Begovich AB: A large-scale genetic association study confirms ILI2B and leads to the identification of IL23R as psoriasis-risk genes. Am J Hum Genet 2007, 80:273-90

FlOOOPrime

65. Kenna TJ, Brown MA: The role of IL-17-secreting mast cells in inflammatory joint disease. Nat Rev Rheumatol 2013, 9:375-9.

66. Schett G, Elewaut D, Mclnnes IB, Dayer JM, Neurath M: How cytokine networks fuel inflammation: Toward a cytokine-based 6disease taxonomy. Nat Med 20I3, 19:822-4.

67. Gregory AP, Dendrou CA, Attfield KE, Haghikia A, Xifara DK, Butter F, Poschmann G, Kaur G, Lambert L, Leach OA, Prömel S, Punwani D, Felce JH, Davis SJ, Gold R, Nielsen FC, Siegel RM, Mann M, Bell Jl, McVean G, Fugger L: TNF receptor I genetic risk mirrors outcome of anti-TNF therapy in multiple sclerosis. Nature 2012, 488:508-I I.

\section{FlOOOPrime}

\section{RECOMMENDED}

68. Bosch X, Saiz A, Ramos-Casals M; BIOGEAS Study Group: Monoclonal antibody therapy-associated neurological disorders. Nature Rev Neurol 20II, 7:165-72.

69. Comabella $M$, Lünemann JD, Río J, Sánchez $A$, López $C$, Julià $E$, Fernández M, Nonell L, Camiña-Tato M, Deisenhammer F, Caballero E, Tortola MT, Prinz M, Montalban X, Martin R: A type I interferon signature in monocytes is associated with poor response to interferon-beta in multiple sclerosis. Brain 2009, 132:3353-65.

\section{FlOOOPrime
RECOMMENDED}

70. Hundeshagen A, Hecker M, Paap BK, Angerstein C, Kandulski O, Fatum C, Hartmann C, Koczan D, Thiesen HJ, Zettl UK: Elevated type I interferon-like activity in a subset of multiple sclerosis patients: molecular basis and clinical relevance. J Neuroinflammation 2012, 9:140.

\section{FlOOOPrime}

\section{RECOMMENDED}

7I. Axtell RC, Raman C, Steinman L: Type I interferons: beneficial in Th I and detrimental in ThI7 autoimmunity. Clin Rev Allergy Immunol 2013, 44: $114-20$.

72. Vosslamber S, Raterman HG, van der Pouw Kraan TC, Schreurs MW, von Blomberg BM, Nurmohamed MT, Lems WF, Dijkmans BA, Voskuyl $A E$, Verweij CL: Pharmacological induction of interferon type I activity following treatment with rituximab determines clinical response in rheumatoid arthritis. Ann Rheum Dis 201I, 70:1153-9.

\section{FlOOOPrime}

\section{RECOMMENDED}

73. Raterman HG, Vosslamber S, de Ridder S, Nurmohamed MT, Lems WF, Boers M, van de Wiel M, Dijkmans BA, Verweij CL, Voskuyl A: The interferon type I signature towards prediction of non-response to rituximab in rheumatoid arthritis patients. Arthritis Res Ther 2012, I4:R95.

\section{FIOOOPrime}

74. Sellam J, Marion-Thore S, Dumont F, Jacques S, Garchon HJ, Rouanet S, Taoufik Y, Hendel-Chavez H, Sibilia J, Tebib J, Le Loët X, Combe B, Dougados M, Mariette X, Chiocchia G: Use of whole-blood transcriptomic profiling to highlight several pathophysiologic pathways associated with response to rituximab in patients with rheumatoid arthritis: data from a randomized, controlled, open-label trial. Arthritis Rheumatol 20I4, 66:20I5-25.

\section{FlOOOPrime
RECOMMENDED}

75. Chan AC, Behrens TW: Personalizing medicine for autoimmune and inflammatory diseases. Nat Immunol 2013, 14:106-9.

\section{FlOOOPrime}

RECOMMENDED

76. Smilek DE, Ehlers MR, Nepom GT: Restoring the balance: immunotherapeutic combinations for autoimmune disease. Dis Model Mech 2014, 7:503-I3. 